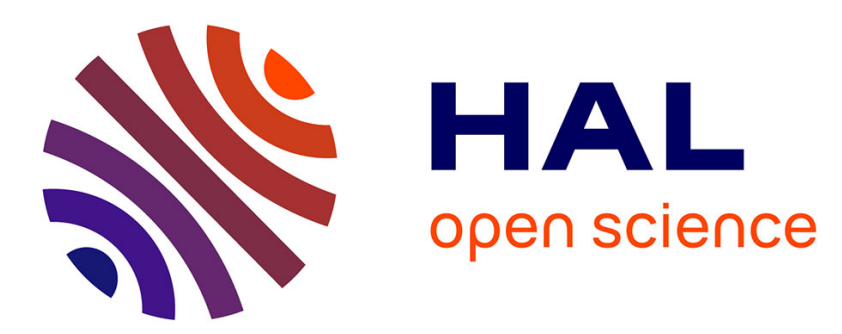

\title{
Peptide immobilization onto radiation grafted PVDF-g-poly(acrylic acid) films
}

\author{
M.-C Clochard, N Betz, M Goncalves, C Bittencourt, J.-J Pireaux, K
}

Gionnet, G Déléris, A Le Moël

\section{- To cite this version:}

M.-C Clochard, N Betz, M Goncalves, C Bittencourt, J.-J Pireaux, et al.. Peptide immobilization onto radiation grafted PVDF-g-poly(acrylic acid) films. Nuclear Instruments and Methods in Physics Research Section B: Beam Interactions with Materials and Atoms, 2005, 236, pp.208. 10.1016/j.nimb.2005.04.029 . hal-01129026

\section{HAL Id: hal-01129026 \\ https://hal.science/hal-01129026}

Submitted on 11 Mar 2015

HAL is a multi-disciplinary open access archive for the deposit and dissemination of scientific research documents, whether they are published or not. The documents may come from teaching and research institutions in France or abroad, or from public or private research centers.
L'archive ouverte pluridisciplinaire HAL, est destinée au dépôt et à la diffusion de documents scientifiques de niveau recherche, publiés ou non, émanant des établissements d'enseignement et de recherche français ou étrangers, des laboratoires publics ou privés. 


\title{
Peptide immobilization onto radiation grafted PVDF-g-poly(acrylic acid) films
}

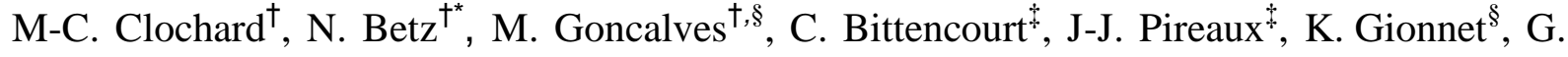 \\ Déléris $^{\S}$, A. Le Moël ${ }^{\dagger}$ \\ ${ }^{\dagger}$ CEA Saclay, DSM/DRECAM/LSI/LPI, Bat 466, 91191 Gif-sur Yvette Cédex, France. \\ ${ }^{*}$ LISE, FUNDP, 61 Rue de Bruxelles, B-5000 Namur, Belgique. \\ ${ }^{\S}$ INSERM U.443, University Victor Segalen-Bordeaux II, 146 Léo Saignat, 33076 Bordeaux Cédex, France.
}

\section{corresponding author : betz@cea.fr.}

\begin{abstract}
Introducing hydrophilic functions on poly(vinylidene fluoride) (PVDF) films surface allows the covalent immobilization of peptides. Therefore radiation grafting of acrylic acid (AA) in pre-irradiated PVDF films was achieved to allow surface functionalization with linear and cyclic peptides. Peptides were bound via spacer molecules using EDC as a coupling agent. The reactions were followed by Fourier Transform Infrared (FTIR) spectroscopy in attenuated total reflection (ATR) mode. The amount of immobilized peptides was determined by UV spectroscopy. As well, an uncommon method for PVDF characterization and reactions quantification was used: HR-MAS NMR. Spacer saturation of the film surface corresponded to $25 \mathrm{~mol} \%$ yield meaning that one spacer on 4 carboxylic acids was covalently bound. XPS experiments were also performed to deepen analysis of the surface composition. Peptide density is governed by steric hindrance. ELISA tests showed that the peptides' activity is maintained.
\end{abstract}

PACS: $61.41,82.35,78.30 \mathrm{~J}, 61.82 \mathrm{P}$

Keywords: PVDF, PAA, radiation grafting, peptide immobilization, coupling agent, ELISA 


\section{Introduction}

Angiogenesis constitutes a physiological response to ischemia [1,2]. Neovascularization of ischemic cardiac or skeleton muscle may be sufficient to preserve tissue integrity and may thus be considered to be therapeutic. The biological activity may be brought by small peptides miming the vascular endothelial growth factor (VEGF) effect on angiogenesis response [3]. Immobilizing such peptides onto a solid polymeric support is of great interest for biomedical applications.

In the present work, we have chosen poly(vinylidene fluoride) (PVDF) as polymeric support. It is a fluorinated thermoplastic polymer which is biocompatible and can be processed in various forms. Ionizing radiation on PVDF allows hydrophobic PVDF films to endow hydrophilic properties by grafting acrylic acid (AA). In a previous study [4], we have shown that, under certain conditions, PAA totally covers the PVDF surface. All PAA carboxylic acids become consequently as many anchoring sites to immobilize peptides. In order to bring mobility to the peptides, spacer molecules have to be introduced. In addition, these may be designed to undergo enzymatic cleavage depending on the application requirements. This paper reports on subsequent coupling reactions which have been carried out and followed by FTIR, HR-MAS NMR and XPS. Chemistry synthesis details are discussed and immobilized peptide activity has been also investigated.

\section{Experimental Section}

\subsection{Materials and Reagents.}


Hydrophobic $25 \mu \mathrm{m}$ thick $\alpha$ PVDF films (Atochem) were Soxhlet-extracted in toluene and dried at $50{ }^{\circ} \mathrm{C}$ under vacuum before use. The following chemicals and bio-chemicals were purchased from Sigma-Aldrich and used as received: acrylic acid (AA), Mohr's salt $\left[\mathrm{FeH}_{8} \mathrm{~N}_{2} \mathrm{O}_{8} \mathrm{~S}_{2} \cdot 6 \mathrm{H}_{2} \mathrm{O}\right]$, ethyl-3-(3-dimethylaminopropyl)carbodiimide $\mathrm{C}_{8} \mathrm{H}_{17} \mathrm{~N}_{3} \cdot \mathrm{HCl}$ (EDC), trifluoroacetic acid (TFA), sulphuric acid $\mathrm{H}_{2} \mathrm{SO}_{4}, \mathrm{~N}$-hydroxysuccinimide (NHS), acetate buffer (pH 5), 3,3',5,5'-tetramethylbenzidine (TMB), bovine serum albumin (BSA), $0.05 \%$ Tween-20 in phosphate buffered solution (PBS-Tween), primary antibody DB4, peroxydaseconjugated anti-mouse IgG (secondary antibody). Peptides were synthesized by INSERM U577's team (Bordeaux, France) : P(242-261) H-Ser-Pro-Asn-Val-Ser-Val-Pro-Ser-Ser-SerSer-Thr-Pro-Leu-Leu-Tyr-Pro-Ser-Leu-Ala-OH (2 003.2 g/mol), P(253-261) (1 031 g/mol), P(236-245) HO-Thr-Trp-His-Val-Leu-Tyr-Ser-Pro-Asn-Val-H (1 213 g/mol), P(237-245) (1 $114.2 \mathrm{~g} / \mathrm{mol}$ ) and P11, a cyclic peptide of 17 aminoacids (2 $000 \mathrm{~g} / \mathrm{mol}$ ) [3]. The spacer used, noted TEG, is a functionalized triethyleneglycol with an amine function at one end and a tertio-butyl protected carboxyl acid at the other end. It was synthesized at the INSERM. Ionexchange water was used needed.

2.2. Immobilization of peptides via a spacer on poly(acrylic acid)-radiation-grafted PVDF [Scheme 1].

Films were irradiated at RT under helium at $150 \mathrm{kGy}$ (dose-rate : $500 \mathrm{kGy} / \mathrm{h}$ ) using a 2.5 $\mathrm{MeV}$ Van de Graaf accelerator. Immediately after irradiation films were stored under nitrogen atmosphere at RT. Grafting $\left(1 \mathrm{~h}, 60^{\circ} \mathrm{C}\right)$ is performed in a pure AA solution with 25 wt $\%$ concentration of Mohr's salt using the procedure described in [5]. PVDF-g-PAA films with a grafting yield of $10 \mathrm{wt} \%$ (ca. $16 \mu \mathrm{mol}$ of AA) were first coupled to TEG in EDC aqueous solution $(160 \mu \mathrm{mol}$ in $50 \mathrm{ml},[\mathrm{TEG}] /[\mathrm{EDC}]=1)$. Reaction ran $4 \mathrm{~h}$ at $\mathrm{RT}$ and gave $25 \mathrm{~mol} \%$ 
yields. The films were immersed in TFA / $\mathrm{H}_{2} \mathrm{O}(95 \mathrm{v} \%)$ for $1 \mathrm{~h}$ at $70{ }^{\circ} \mathrm{C}$. Films were activated in $1.76 \mathrm{mM}$ EDC and $1.78 \mathrm{mM}$ NHS for $4 \mathrm{~h}$ at RT. Films were washed in water and equilibrated with $0.7 \mathrm{M}$ acetate buffer ( $\mathrm{pH}$ 5). The NHS activated films were immersed for 48 $\mathrm{h}$ in $0.7 \mathrm{M}$ acetate buffer containing peptides $(0.339 \mathrm{mg} / \mathrm{ml})$.

\subsection{Spectroscopic characterization.}

FTIR spectra of the polymer films were carried out with a Nicolet Magna-IR ${ }^{\mathrm{TM}} 750$ spectrometer equipped with a DTGS detector. Spectra were recorded in Attenuated Total Reflection mode (ATR) using a diamond-crystal with single reflection cumulating 32 scans at a resolution of $2 \mathrm{~cm}^{-1}$.

Quantitative determination of linear and cyclic peptides in acetate buffer was performed using a UV-visible spectrometer UNICAM UV 300. Calibration curves were obtained at $280 \mathrm{~nm}$ and $220 \mathrm{~nm}$ corresponding to the specific maximum of linear and cyclic peptide UV absorption respectively.

HR-MAS NMR spectroscopy experiments were performed using an Avance 500 spectrometer equipped with an HR-MAS dual probe $\left({ }^{1} \mathrm{H} /{ }^{13} \mathrm{C}\right)$ and $4 \mathrm{~mm}$ HR-MAS Rotor $\left(\mathrm{ZrO}_{2}\right)$-no insert. Deuterated DMF, solvent of both PVDF and PAA, was used.

X-ray photoelectron (XPS) spectra were recorded on a HP5950A spectrometer using a monochromatic Al Ka X-ray source. A flood gun was used to cancel charging-up effects. The resolution was $0.8-1 \mathrm{eV}$. Binding energies were determined by reference to the $\mathrm{C}_{1 \mathrm{~S}}$ component due to carbon bond set at $285 \mathrm{eV}$. Linear baseline for background subtraction and Gaussian functions were used for peak fitting. Atomic percentages were determined from peak areas by using Scofield factors [6]. 


\subsection{ELISA test}

An antigenic peptide and a control peptide corresponding respectively to the sequences 242-261 and 237-245 of the Gp46 protein from the Human T-cell Lymphotropic Virus (HTLV-1) were synthesized and immobilized on PVDF-g-PAA (section 2.2). Films were placed into wells of a 12-well plates. The plates were covered and incubated in a blocking solution (3\% BSA in PBS-Tween) under stirring at $37^{\circ} \mathrm{C}$ for $1.5 \mathrm{~h}$. After washing in PBS-Tween, $500 \mu \mathrm{L}$ of diluted primary antibody DB4 (1/80000 in 1\% BSA in PBSTween) were added to selected wells. After covering, samples were incubated at $4{ }^{\circ} \mathrm{C}$ for $18 \mathrm{~h}$ under stirring and washed. Then, diluted secondary antibody solution $(1 / 10000$ in $1 \%$ BSA in PBS-Tween) was added, plates were covered, incubated under stirring at $37{ }^{\circ} \mathrm{C}$ for $1 \mathrm{~h}$ and washed. TMB (500 $\mu \mathrm{L} /$ well $)$ was added, plates were covered and incubated at room temperature for 15 min under stirring. Reactions were stopped by $0.5 \mathrm{M} \mathrm{H}_{2} \mathrm{SO}_{4}$. Tests were run in triplicate. Reaction supernatants were transferred to a 96-well plate and absorbance was read at $450 \mathrm{~nm}$ in a MRX microplate reader (Dynex technologies). Two ELISA controls (one without primary antibody and another without solid support) were run to ensure that the colorimetric reaction was due to the molecular recognition and not to a non-specific reaction.

\section{Results and Discussion}

\subsection{FTIR characterization and UV backtitration}

Under our experimental conditions, surface grafting was favored [4,5]. The chemical functions of PVDF-g-PAA (1) copolymer films are identified by FTIR (Figure 1) and were specified in detail in a previous work [5]. Scheme 1 illustrates all chemical steps from PVDF- 
g-PAA (1) copolymers to PVDF-g-PAA-TEG-Peptide (5) films. A first step consists in attaching the TEG spacer onto grafted films to bring mobility to the future immobilized peptide. Covalent linkage of TEG is achieved through chemical coupling of its amino groups to the PAA carboxyl groups using a water-soluble carbodiimide (EDC). Figure 2 displays specific IR peaks of amide bond formation at $1644 \mathrm{~cm}^{-1}$ and $1547 \mathrm{~cm}^{-1}$ as well as the characteristic TEG absorptions (t-butyl, $\mathrm{CH}_{2}$, ester and ether vibrations at $2980 \mathrm{~cm}^{-1}$, $2860 / 2870 \mathrm{~cm}^{-1}, 1726 \mathrm{~cm}^{-1}$ and $1100 \mathrm{~cm}^{-1}$, respectively). After $t$-butyl cleavage step (scheme 1), a second coupling reaction is performed to attach the peptide by coupling its amino groups to the TEG carboxylic acid groups using EDC and NHS. PVDF-g-PAA-TEG (3) acid groups are activated with NHS which leads to the intermediate PVDF-g-PAA-TEG-NHS (4). Primary amine groups are well known to react specifically with NHS activated carboxyl acids. By this way, there is no need to protect the terminal carboxylic acid of the peptide to avoid peptide homopolymerization. Three peptides have been used : two linear ones, $\mathrm{P}(253$ 261) and P(236-245), and a cyclic one, noted P11 [3]. The last one specifically mimes the VEGF effect on angiogenesis [7]. In Figure 3, the ester vibration corresponding to NHS activated carboxyl acid group is clearly observed at $1732 \mathrm{~cm}^{-1}$ as well as the succinic ester N$\mathrm{O}$ vibration at $1205 \mathrm{~cm}^{-1}$. Immobilization of peptides induces a significant decrease of these peaks which indicates that most of NHS sites on the surface have reacted. The residual absorptions are due to a lack of accessibility of NHS activated acids to peptide molecules due to steric hindrance in relation to heterogeneous phase reaction.

The amounts of covalently immobilized peptides are evaluated by performing UV spectra of supernatant peptide solution. The resulting yield is found equal to $12 \mathrm{~mol} \%$ in TEG equivalent (similar to $10 \pm 2.2 \mathrm{~mol} \%$ found gravimetrically) for linear peptides and $7.38 \mathrm{~mol}$ $\%$ for cyclic ones. This is a high binding density value, even if it is finally equal to only 0.24 mol \% of initial PVDF repeat units. 1 linear peptide molecule is then immobilized for 10 TEG 
molecules and 1 cyclic peptide molecule for 15 TEG molecules. Indeed, binding densities are governed by their individual three-dimensional space requirements.

\section{2. ${ }^{1} \mathrm{H}$ and ${ }^{13} \mathrm{C}$ HR-MAS NMR characterization}

Irradiation is performed at an absorbed dose higher than the gel dose. Therefore PVDF is crosslinked and films are not fully soluble in DMF anymore. Solid state spectra, in such a case, generally display a poor resolution. A solution to this dilemma is to swell the films with the DMF and to acquire spectra while spinning at magic angle. Figure 4 shows a protoncarbon correlation spectrum of a highly grafted PVDF film swollen in DMF-d7. ${ }^{1} \mathrm{H}$ spectrum displays large peaks at $1.979 \mathrm{ppm}$ and $1.722 \mathrm{ppm}$ corresponding to the $\mathrm{CH}_{2}$ of PAA. One would expect only one signal at $1.722 \mathrm{ppm}$. The chemical shift observed for $33 \%$ of the PAA $\mathrm{CH}_{2}$ at 1.979 ppm may be attributed to $\mathrm{CH}_{2}$ bound directly on a $\mathrm{CF} / \mathrm{CF}_{2}$ of PVDF or on a peroxide. At $2.502 \mathrm{ppm}$, a large peak is seen which is due to the superimposition of the $\mathrm{CH}$ of PAA and a triplet corresponding to the $\mathrm{CH}_{3}$ of PVDF chain ends. These chain ends (around $10 \mathrm{~mol} \%$ of PVDF) are assumed to come from PVDF chain scissions during radiation process. The large multiplet at $3.038 \mathrm{ppm}$ is the $\mathrm{CH}_{2}$ of PVDF repeat unit signal. Carbon peaks of PVDF are detected at 23 ppm for chain ends, a triplet at 43 ppm for $\mathrm{CH}_{2}$ and a wellresolved triplet at $120 \mathrm{ppm}$ for $\mathrm{CF}_{2}$. From integrated signals, a quantitative approach allows us to evaluate accurately the AA/PVDF ratio. For example, a PAA yield of $7.23 \mathrm{~mol} \%$ is calculated from HR-MAS NMR spectrum of a $10 \mathrm{w} \%$ grafted PVDF while 6 mol \% are obtained from gravimetric measurements. The spectra of 5 presented in Figure 5 evidences the covalent linkage of the peptide by the presence of well-defined aromatic ${ }^{1} \mathrm{H}$ peaks. The yield of immobilized peptide is calculated from the HR-MAS NMR spectrum as $2\left(\mathrm{I}_{\text {arom }} / 11\right) /($ $\left.\mathrm{I}_{\mathrm{PVDF}}-6 \times \mathrm{I}_{\mathrm{DMF}}\right)$, where $\mathrm{I}_{\text {arom }}$ is the peak area of the signal of the 11 aromatic peptide protons, 
$\mathrm{I}_{\mathrm{PVDF}}$ is the peak area of the $\mathrm{CH}_{2}$ PVDF signal (two protons) and $\mathrm{I}_{\mathrm{DMF}}$ is the peak area of $\mathrm{CH}$ DMF at $8.2 \mathrm{ppm}$. Calculation gives $0.18 \mathrm{~mol} \%$ of PVDF repeat units for one immobilized peptide. In comparison, the UV titration gave a peptide/PVDF ratio of 0.24 mol \% while 0.19 mol \% is obtained gravimetrically.

\subsection{XPS characterization}

Table 1 summarizes atomic ratios obtained from XPS survey spectra (not shown) while Figure 6 presents the $C_{1 s}$ lines. Virgin PVDF exhibits in addition to the expected $C$ and $F$ content, little oxidation (3.2\%) due to film storage. After grafting, a huge increase of oxygen percentage is observed due to PAA carboxylic acids. F signal decreases to less than $1 \%$. There is a significant increase in the $\mathrm{N}$ content going from TEG to peptide coupling reactions. Further information on PVDF surface modification is obtained from the $\mathrm{C}_{1 \mathrm{~s}}$ spectra. Virgin PVDF $\mathrm{C}_{1 \mathrm{~s}}$ spectrum displays two peaks at 286.6 and $291.1 \mathrm{eV}$ for $\mathrm{CH}_{2}$ and $\mathrm{CF}_{2}$, respectively. After grafting, PVDF peaks are no longer visible and three carbon peaks corresponding to PAA groups are observed at $284.8 \mathrm{eV}, 285.2 \mathrm{eV}$ and $289 \mathrm{eV}$ for $\mathrm{CH}_{2}, \mathrm{CH}$ and $\mathrm{COOH}$ respectively [8]. This means that the grafted PAA is located on the surface with $100 \%$ of coverage [4]. $\mathrm{C}_{1 \mathrm{~s}}$ spectrum of 2 displays a high ether peak at $286.6 \mathrm{eV}$ specific of TEG presence. The amide peak, present in $\mathrm{C}_{1 \mathrm{~s}}$ spectrum of $\mathbf{2}$, dramatically increases at $288.4 \mathrm{eV}$ on $\mathrm{C}_{1 \mathrm{~s}}$ core level spectrum of $\mathbf{5}$. $\mathrm{C}_{1 \mathrm{~s}}$ features of $\mathbf{5}$ assignment is in agreement with other studies on peptide characterization $[9,10]$. A $\pi \pi^{*}$ characteristic shake-up of aromatic carbons hold by $\mathrm{P}(236-245)$ is also detected at $291 \mathrm{eV}$. O/C, N/C and N/O ratios of $\mathbf{5}$ correspond to the calculated value of a peptide molecule for 10 TEG molecules. This confirms the UV results. Consequently, it is concluded that the peptide is mainly located on the surface of functionalized grafted PVDF films. 
In order to evaluate peptide's activity after immobilization, ELISA tests were performed to determine if molecular recognition is still possible after grafting of the antigenic peptide on the functionalized solid support. Results (Figure 7) are evaluated by comparing : i) the O.Ds of each samples to their respective control (i.e without antibody DB4) to evaluate non-specific reaction of the secondary antibody, ii) the O.Ds resulting from the samples with antigen and iii) the O.Ds resulting from the samples with control peptide to determine nonspecific reaction of the antibody DB4. Non-specific reaction with BSA from blocking solution was evaluated for measurement correction. O.D variation obtained for PVDF-g-PAA-TEGantigen compared to all the other films and control experiments is sufficiently significant to conclude that antigen-antibody specificity is maintained.

\section{Conclusion}

In investigated conditions, electron beam irradiation permits us to obtain PAA covalently grafted onto the PVDF film surface. We have shown that the immobilization of peptides onto PVDF-g-PAA films surface via a spacer can be easily obtained by coupling reactions in mild conditions. All chemical functionalizations take place mainly on the films surface and yields are governed by steric hindrance considerations. Immobilized peptides are located in the first nanometers of films surface. Among several spectroscopic techniques, HR-MAS NMR appears to be the most accurate technique to detect low peptide quantities. In addition, HRMAS NMR may also give us information about secondary structure of peptide bound to solid supports [11]. It would be then interesting to exploit this property to compare with biological 
data. Indeed, PVDF-g-PAA-TEG-peptide copolymer films offer a great biomedical interest. By varying peptide sequences and spacer, it may be possible to develop a panel of applications in diagnosis and medical therapy.

\section{Acknowledgements}

This work was performed in the frame of the LRC 98-15. The financial support by a grant from Lefoulon-Delalande Foundation (Institut de France, Paris) attributed to MCC is gratefully acknowledged. MG acknowledges the CEA and the Conseil Régional d'Aquitaine for providing him a Ph D grant. The authors thank Olivier Assemat from Brüker Biospin S.A. for its contribution to HR-MAS NMR spectra.

\section{References}

[1] I. Stein, M. Neeman, D. Shweiki, A. Itin, E. Keshet, Molecular and Cellular Biology 15 (1995) 5363.

[2] T. Couffinhal, M. Silver, P. Zheng Lhu, M. Kearney, B. Witzenbichler, J. M. Isner, American Journal of Pathology 152 (1998) 1667.

[3] N. Betz, A. Bikfalvi, G. Deleris, Patent No. 0012654 (2000).

[4] M.-C. Clochard, J. Bègue, A. Lafon, N. Betz, D. Caldemaison, C. Bittencourt, J.-J. Pireaux, Polymer (2004) (submitted).

[5] N. Betz, J. Bègue, M. Goncalves, K. Gionnet, G. Déléris, A. Le Moël, Nuclear instruments and Methods in Physics Research B 208 (2003) 434.

[6] J. H. Scofield, J. Electron Spectrosc. Relat. Phenom. 8 (1976) 129.

[7] L. Zilberberg, S. Shinkaruk, O. Lequin, B. Rousseau, M. Hagedorn, F. Costa, D. Caronzolo, M. Balke, X. Canron, O. Convert, G. Lain, K. Gionnet, M. Goncalves, M. Bayle, L. Bello, G. Chassaing, G. Deleris, A. Bikfalvi, Journal of Biological Chemistry 278 (2003) 35564.

[8] G. Beamson, D. Briggs, in, High Resolution Xps of Organic Polymers: The Scienta Esca300 Database, John Wiley \& Sons Ltd., 1992.

[9] Y. F. Dufrêne, A. Van der Wal, W. Norde, P. G. Rouxhet, Journal of Bacteriology 179 (1997) 1023.

[10] S. S. Lateef, S. Boateng, T. J. Hartman, C. A. Crot, B. Russell, L. Hanley, Biomaterials 23 (2002) 3159.

[11] J. Furrer, M. Piotto, M. Bourdonneau, D. Limal, G. Guichard, K. Elbayed, J. Raya, J.-P. Briand, A. Bianco, J. Am. Chem. Soc. 123 (2001) 4130. 


\section{Figure captions}

Scheme 1. Reaction scheme of PVDF-g-PAA-TEG-peptide synthesis

Figure 1. FTIR/ATR spectra of electron irradiated PVDF and PVDF-g-PAA.

Figure 2. FTIR/ATR spectra of PVDF-g-PAA film before (‥) and after (-) TEG binding.

Figure 3. FTIR/ATR spectra of (...) PVDF-g-PAA-spacer-COO-NHS (4) and (-) PVDF-gPAA-TEG-peptide (5).

Figure 4. 2D HR MAS $500 \mathrm{MHz}{ }^{1} \mathrm{H}^{-13} \mathrm{C}$ HSQC spectrum of PVDF-g-PAA film swollen in DMF-d7 (grafting yield of $123 \mathrm{w} \%$ ).

Figure 5. HR MAS 500 MHz spectrum of PVDF-g-PAA-TEG-P(236-245) swollen in DMF$\mathrm{d} 7$.

Figure 6. $\mathrm{C}_{1 \mathrm{~S}}$ core level X-ray photoelectron spectra: $(\Delta)$ raw data; $\cdots$ Base line; - fit; decomposition: $\mathrm{PVDF}(\nabla) \underline{\mathrm{C}} \mathrm{H}_{2},(\boldsymbol{\square}) \underline{\mathrm{CF}}_{2} ;(\square) \underline{\mathrm{C}}=\mathrm{O}$ oxidation ; (O) $\underline{\mathrm{CH}}_{2}$ PAA / $\underline{\mathrm{C}}$ aliphatic + aromatic P(236-245); ( $\boldsymbol{\nabla}) \underline{\mathrm{C}} \mathrm{H}$ PAA; (•) COO PAA/ester TEG/acid P(236-245) ; ( $\mathbf{\Delta}) \underline{\mathrm{C}}-\mathrm{N}$ amide/amine $\mathrm{P}(236-245) ;(\diamond) \underline{\mathrm{CO}}$ ether/alcohol; (a) NH- $\underline{\mathrm{C}}=\mathrm{O}$ amide; $(-\bullet-)$ shake-up $\mathrm{P}(236-$ 245).

Figure 7. ELISA test on pristine PVDF, irradiated PVDF, PVDF-g-PAA (1), PVDF-g-PAATEG (2), BSA 3\% and two PVDF-g-PAA-TEG-peptides (5) containing an antigen P(242261) and the control $\mathrm{P}(237-245)$. 


\section{Table caption}

Table 1. Atomic percentage of $\mathrm{C}, \mathrm{O}, \mathrm{F}$ and $\mathrm{N}$ from XPS for each step of the surface functionalization; PAA grafting yield is of $10 \%$.

\begin{tabular}{|c|c|c|c|c|}
\hline Samples & $\mathrm{C}_{1 \mathrm{~S}}(\%)$ & $\mathrm{F}_{1 \mathrm{~S}}(\%)^{*}$ & $\mathrm{O}_{1 \mathrm{~S}}(\%)$ & $\mathrm{N}_{1 \mathrm{~S}}(\%)$ \\
\hline PVDF & 49.3 & 47.5 & 3.2 & 0 \\
\hline PVDF-g-PAA (1) & 61.4 & 0.4 & 37.7 & 0 \\
\hline PVDF-g-PAA-TEG (2) & 73.3 & 0.2 & 22.9 & 3.6 \\
\hline PVDF-g-PAA-TEG-P(236-245) (5) & 69.3 & 0.7 & 22.0 & 8.0 \\
\hline
\end{tabular}




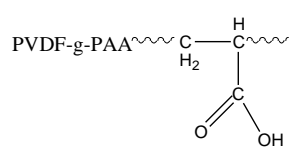

PVDF-g-PAA (1)
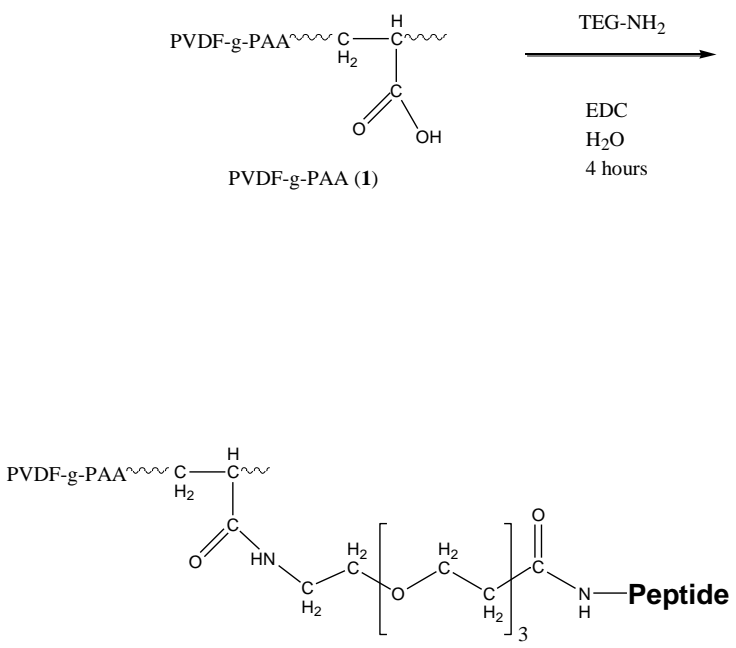

PVDF-g-PAA-TEG-Peptide (5)

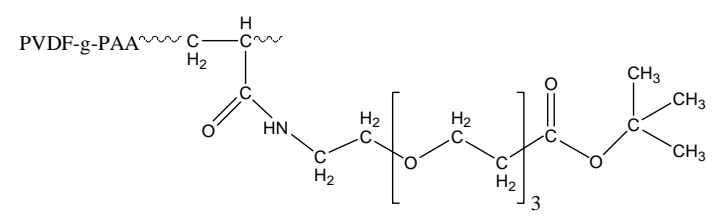

PVDF-g-PAA-TEG (2)

$\mathrm{CF}_{3}-\mathrm{COOH} / \mathrm{H}_{2} \mathrm{O}(95 \mathrm{v} \%)$ $70^{\circ} \mathrm{C}, 1$ hour

PVDF-g-PAA-TEG (3)

N-hydroxysuccinimide EDC, H2O, RT, 4 hours

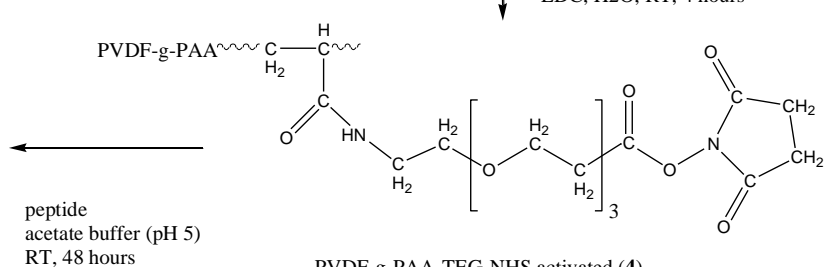

PVDF-g-PAA-TEG-NHS activated (4)

Scheme 1.
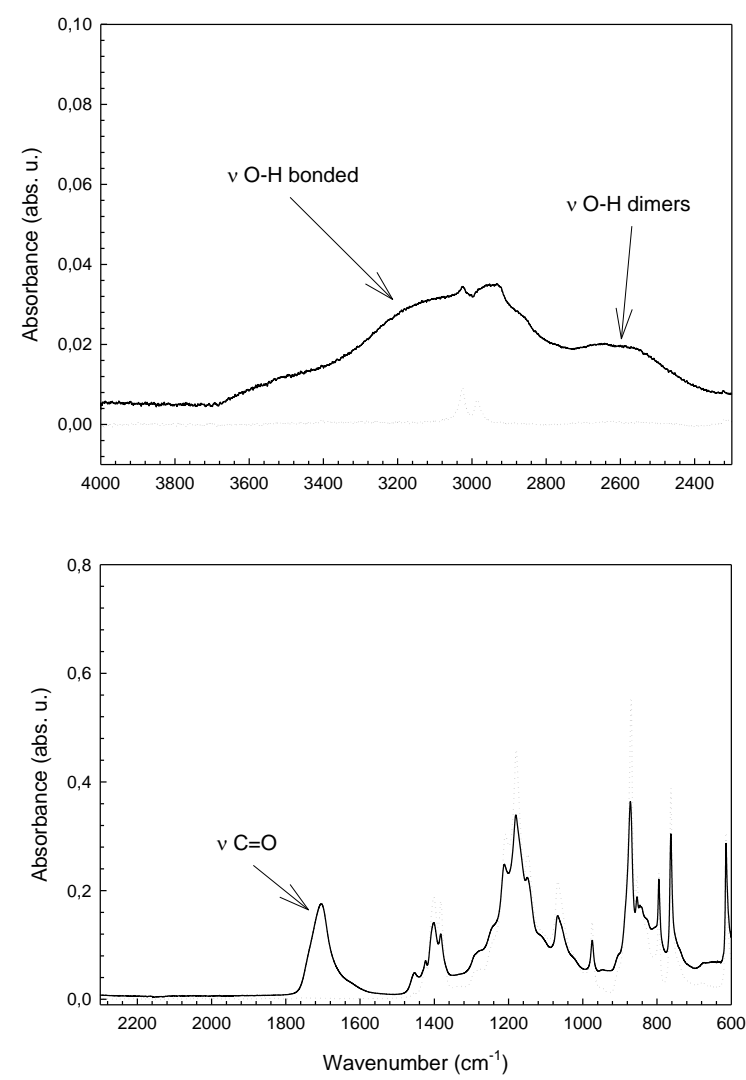

Figure 1. 

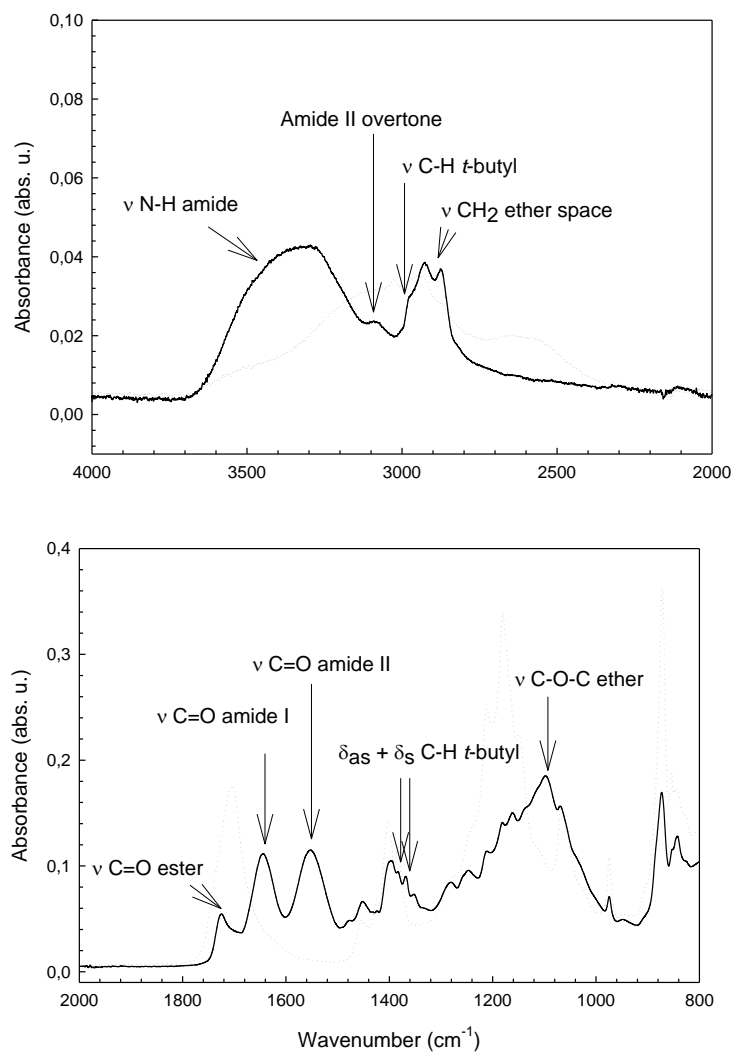

Figure 2.

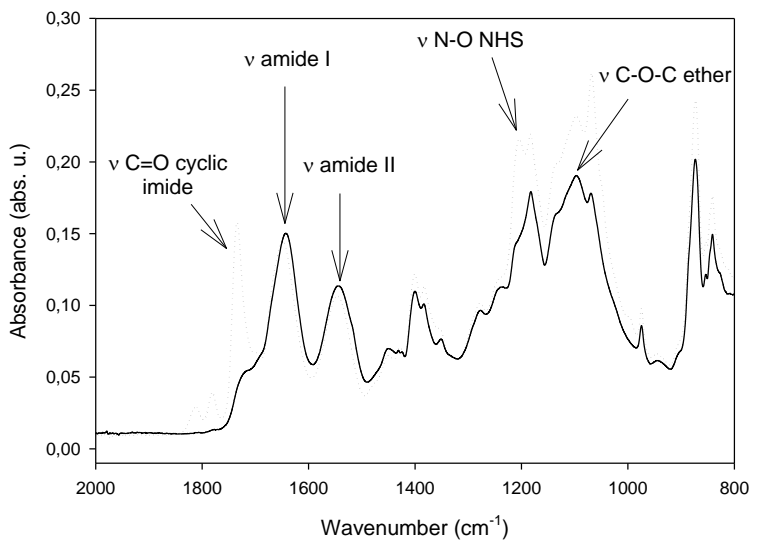

Figure 3. 


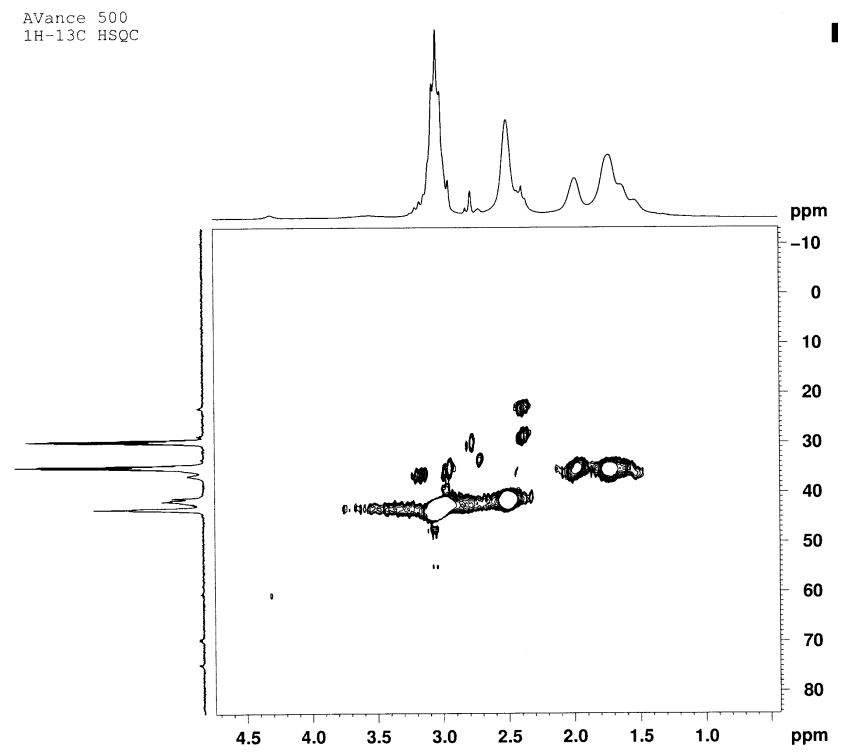

Figure 4

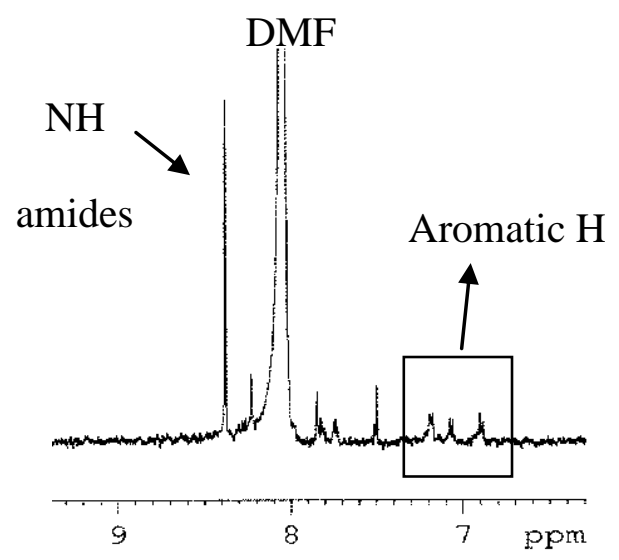

Figure 5 
Figure 6
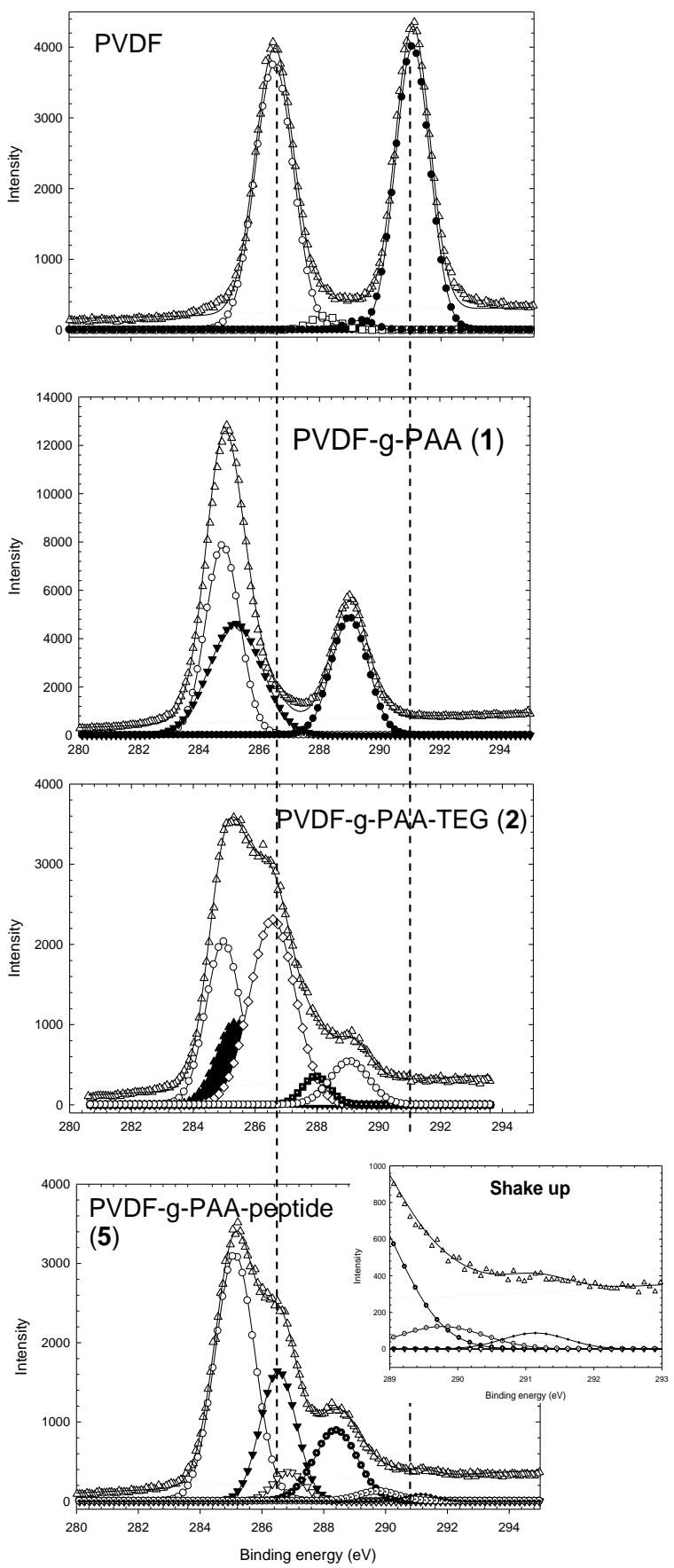


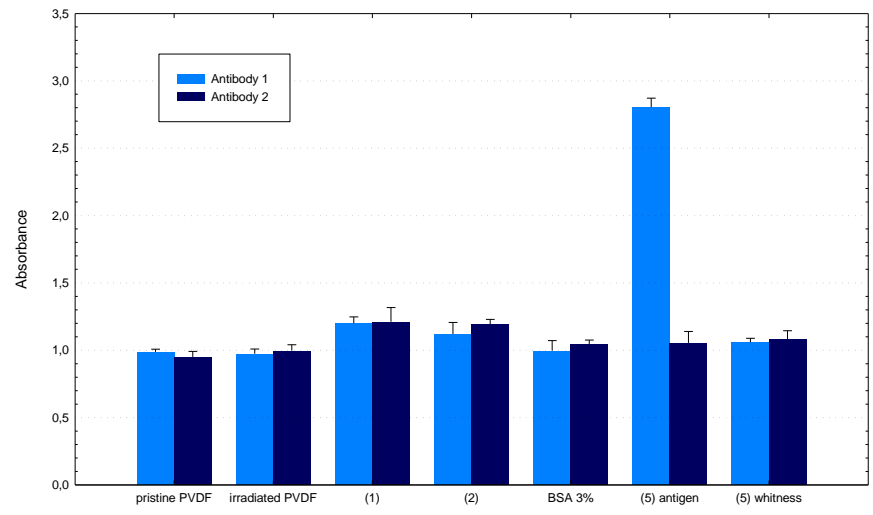

Figure 7 